\title{
Islamic Calendar Anomalies: Pakistani Practitioners' Perspective
}

\author{
Anwar Halari $^{\mathrm{a}^{*}}$, Christine Helliar ${ }^{\mathrm{b}}$, David. M. Power ${ }^{\mathrm{c}}$, Nongnuch Tantisantiwong ${ }^{\mathrm{d}}$ \\ ${ }^{\text {a }}$ Faculty of Business and Law, The Open University, Walton Hall, Milton Keynes, MK7 6AA, UK \\ Email: anwar.halari@open.ac.uk \\ b School of Commerce, University of South Australia, Adelaide, SA 5001, Australia \\ Email: Christine.helliar@unisa.edu.au \\ c School of Social Sciences, University of Dundee, 1 Perth Road, Dundee, DD1 4HN, UK \\ Email: D.m.power@dundee.ac.uk \\ d Southampton Business School, University of Southampton, Southampton, SO17 1BJ, UK \\ E-mail: N.tantisantiwong@soton.ac.uk
}

\begin{abstract}
Purpose

Studies on Islamic calendar anomalies in financial markets tend to apply quantitative analysis to historic share prices. Surprisingly, there is a lack of research investigating whether the participants of such markets are aware of these anomalies and whether these anomalies affect their investment practice. Or is it a case that these practitioners are completely unaware of the anomalies present in these markets and are missing out on profitable opportunities? The purpose of this paper is to analyse the views of influential participants within the Pakistani stock market.
\end{abstract}

\section{Design/methodology/approach}

The study documents the findings for 19 face-to-face semi-structured interviews conducted with brokers, regulators and high-net-worth individual investors in Karachi.

\section{Findings}

The paper's major findings indicate that the participants believed that anomalies were present in the stock market and market participants were actively attempting to exploit these anomalies for abnormal gains. Interviewees suggested that predictable patterns can be identified in certain Islamic months (Muharram, Safar, Ramadan and Zil Hajj). The most common pattern highlighted by the interviews related to the month of Ramadan. Furthermore, interviewees mentioned the influence of the "Memon" community in the Pakistani stock market. Respondents also suggested that investor sentiment played an important role in influencing the stock market prices and trading patterns.

\section{Originality/value}

Since all the prior studies investigating Islamic calendar anomalies in Muslim majority countries adopted quantitative method using secondary data, the current investigation is of particular value since it focuses on the qualitative analyses and reports the views of market participants. This allows to fully explore the topic under investigation and to draw robust conclusions.

Keywords: Investor sentiment. Islamic calendar anomalies, Memon community, Pakistani stock market, Ramadan.

Paper type Research paper

\footnotetext{
* Corresponding Author; Faculty of Business and Law, The Open University, Walton Hall, Milton Keynes, MK7 6AA, United Kingdom; Tel: 01908(6)53578 | Email: anwar.halari @open.ac.uk
} 


\section{Introduction}

To date, all studies investigating Islamic calendar anomalies in Pakistan applied quantitative analysis to historic share prices. None of the prior studies in this area has sought the views of Pakistani stock market participants when investigating Islamic calendar anomalies; therefore, the current study makes a contribution in an area that has not been previously explored. In particular, this study aims: (i) to ascertain the views of Pakistani stock market participants to gain some insights and in-depth understanding of investor perceptions about the share price regularities with regards to the Islamic calendar; and (ii) to ascertain views about the role of investor sentiment in the Pakistani stock market and its impact on investment practice. It was also thought that such interviews would provide some insights into the behaviour of Pakistani investors and supply an in-depth understanding of investor perceptions about share price regularities with regards to the Islamic calendar.

Pakistan, a country with over a 97 percent Muslim population uses the Islamic calendar concurrently with the Gregorian calendar (Rehman and Masood, 2012; Halari et al., 2015). Although Pakistan's financial markets use the Gregorian calendar for business and government in order to coordinate business dealings with the rest of the world, the Islamic calendar is used to date events in the country and mark annual Islamic holidays, such as Eid.

All the financial markets in the country are closed during Muslim festivities and holy days based on the Islamic calendar. For example, the stock markets are closed 9 days (on average) every year to celebrate Islamic holidays and festivals. The Islamic calendar is approximately 11 days shorter than the Gregorian year as it based on lunar months. Due to this, Islamic calendar days vary by a few days each year on the Gregorian calendar. The Islamic calendar, similar to its Gregorian counterpart, has 
twelve months but only a total of either 354 or 355 days in a year (Halari et al, 2015). The 12 Islamic months are: Muharram, Safar, Rabiul Awwal, Rabiul Thani, Jamatul Awwan, Jamatul Thani, Rajab, Shaban, Ramadan, Shawwal, Zil Qa’ad and Zil Hajj. Islamic calendar months vary in significance and emotions that they evoke within the Muslim community. Prior studies has shown that this may have an impact on investment practice of religious observers as well as the market as a whole. This may in fact explain the anomalous behaviour of share prices in the Pakistani market based on the Islamic calendar. Halari et al. (2015) suggest that significant historical Islamic events that occurred in specific months can explain the emotions and behaviour of Muslims at various times of the year. Ramadan, the 9th month of the Islamic calendar, is documented to evoke positive emotions in Muslim observers. This is the month where Muslims observe fasting from dawn to sunset to keep with the commandment of their holy scripture, the Holy Quran. Generally the business activity in the month of Ramadan is different from that in other months due to increase household spending (Halari et al., 2015). During the day, restaurants and shops are generally closed and the financial markets work on a reduced hour basis. In fact, the trading hours at the Karachi Stock Exchange (KSE) are reduced by more than an hour per day during Ramadan (Husain, 1998; Bialkowski et al., 2012; Halari et al., 2015). Zil Hajj, the last month of Islamic calendar, is also religiously significant to Muslims. A large number of Muslim population depart for Mecca, Saudi Arabia to take part in the annual pilgrimage. Muharram, the first month of Islamic calendar, is another scared month for Muslims; specially, the Shia sect of Muslims who observe mourning in remembrance of a tragic incident that took place in the month of Muharram many years ago[1]. This month is also associated with riots and violence between Sunni's and Shia sects of the community. 
Thus, such emotions and behaviour during different Islamic months may have an influence on the investment practices of investors which may result in share price irregularity based on the Islamic calendar. Prior studies have tested this phenomenon by applying quantitative techniques on historic share prices (Husain, 1998; Mustafa, 2008; Al-Ississ, 2010; Bialkowski et al., 2012; Almudhaf, 2012; Al-Khazali, 2014 and Halari et al., 2015). The current study investigates Islamic calendar anomalies in the Pakistani stock market by ascertaining views of market participants. This study aims to provide detailed evidence regarding Islamic calendar seasonality in Pakistani stock market by examining the views of those who are influential within the stock market of Pakistan. In particular, this study reports the views of brokers, regulators and individual investors who are involved in share trading on a daily basis[2].

The remainder of the paper is organised as follows. Section 2 reviews the general literature regarding the Islamic calendar anomalies while Section 3 provides details about the research method. Section 4 discusses the results and finally conclusions are drawn in Section 5.

\section{Literature review}

A number of studies have also sought to explain the anomalous behaviour of stock markets by linking the sentiments of investors to changes in stock market. It is well documented in the literature that investor sentiments can play a role in the investment decision making (Clark and Isen, 1982; Gardner and Vandersteel, 1984). Many behavioural studies have supported the notion of investor sentiment affecting the stock markets. One of the early empirical studies explaining the effect of mood on stock markets was conducted by Saunders (1993). He documented that returns for the NYSE were positive, on average, on sunny days; by contrast, returns were only moderate on days characterised by a lot of cloud. Hirshleifer and Shumway (2003) confirm this 
finding with evidence from a number of international markets; they performed their analysis with data for 26 countries from 1982 to 1997. They found that sunshine was strongly associated with share returns; overall, their study indicated that investor mood affected the stock market.

Moreover, Edmans et al. (2007) indicated that the outcomes of sporting events involving the country as a whole impacted on the stock market of the country. Their paper investigated the stock market reaction to sudden changes in investor mood. The authors documented a significant market decline after soccer losses. Specifically, the authors found that a loss in the Soccer World Cup elimination stage lead to a next-day abnormal stock return of -0.49 percent. They also documented a negative stock market performance after losses in international cricket, rugby, and basketball matches. The authors argued that it was hard to imagine what else but mood could cause this effect.

It is also believed that any heightened faith-experience during religious months affects the mood of investors; it affects their decision making processes and risk assessments which in turn impact on market returns (Al-Ississ, 2010; Keef and Khaled, 2011). This explanation of investor behaviour is consistent with a number of studies that have linked investor sentiment to changes in stock market returns. These studies have sought to identify and explain any calendar-based predictability with regards to investor behaviour. The important role played by religion has been highlighted in several studies that date back to the 1930s (Weber, 1930). For example, Weber (1930) argued that religious beliefs and practice had a significant effect on economic development. The current study acknowledges that religious and social norms can have some bearing on the investment decision. Given that Islamic calendar months differ from each other in the emotions which they evoke within religious observers, the Islamic calendar anomaly may be explained by investor sentiment. Moreover, it is 
established in prior literature that economic and financial activities vary according to difference Islamic months in Muslim counties. This may also result in the anomalous behaviour of share prices (Halari et al., 2015)

One of the first studies that examined the Islamic calendar effect at the KSE was Husain (1998). Analysing daily share prices for 36 individual shares from 1989 to 1993, Husain (1998) found that the share returns declined in the month of Ramadan, but the reduction, in general, was not significant. However, Husain documented a significant decline in return volatility during the month of Ramadan. A more recent study by Seyyed et al. (2005) reported similar results for the Saudi Arabian stock market over the period 1985 to 2000. Consistent with Husain (1998), they discovered no significant change in the mean return but a noticeable decline in stock market volatility during Ramadan. Furthermore, Mustafa (2008) used the KSE-100 index over the period 1998 to 2004 to analyse not only the month of Ramadan but also five other Islamic months. Mustafa (2008) found no Ramadan effect, but reported significant positive returns in the months which followed Ramadan (Shawwal and Zil Qa'ad). The author also reported that the share return volatility was lower in Ramadan, which was in line with the findings documented by prior literature.

Further evidence about the influence of Islamic calendar effects on stock market returns was presented by Al-Ississ (2010). The author examined the effect of religious events during the Muslim holy days of Ramadan and Ashura[3] for 17 Muslim stock markets (including Pakistan) over a 20-year period from 1988 to 2008 and noted that religious experience during the month of Ramadan had a significant positive effect on the returns of Muslim financial markets whereas a negative impact on returns were reported during the holy day of Ashura in the month of Muharram. Similarly, Al-Hajieh et al. (2011) tested for Islamic calendar anomalies in a different mix of Middle Eastern 
stock markets during the period 1992 to 2007 (Bahrain, Egypt, Jordon, Kuwait, Qatar, Saudi Arabia, Turkey and the UAE). They documented higher mean returns during Ramadan for Egypt, Jordan, Kuwait and Turkey stock markets. These were one of the first studies to document significant evidence for the existence of a Ramadan effect in the mean returns.

More recent investigations of the Islamic calendar impact on the stock market was conducted by Bialkowski et al. (2012) and Almudhaf (2012). Bialkowski et al. (2012) investigated share returns during Ramadan for 14 Islamic stock market indices over the period from 1989 to 2007 while Almudhaf (2012) studied seasonal anomalies associated with the stock markets of 12 countries where majority of the population were Muslims (including Pakistan) over 1996 to 2007. Bialkowski et al. (2012) documented strong evidence of higher average mean returns during the month of Ramadan compare to the rest of the Islamic months and a significant lower volatility during Ramadan. The authors suggested that their results were consistent with the belief that Ramadan positively effects investor sentiment. In the same year, Almudhaf (2012) reported evidence of Ramadan seasonality in equity returns for four countries of their sample. The results indicated that a significant Ramadan effect was present (higher returns during Ramadan) in Jordan, Kuwait, Pakistan, and Turkey. Using stochastic dominance (SD) approach, Al-Khazali (2014) revisited the Ramadan effect in the stock returns of 15 Muslim countries (including Pakistan) over the period from 1989 to 2012. The authors reported that the magnitude of Ramadan effect diminished during the recent years and suggested that this is in line with the finance theory which suggests that when an anomaly is discovered, it is eliminated by market participants. The study, however, reports that risk-averse investors would benefit from increased utility by shifting their investment from non-Ramadan to Ramadan months. 
Most recently, Halari et al. (2015) focussed particularly on Pakistan to investigate Islamic calendar anomalies. The authors analysed daily share prices for 106 individual firms listed on the KSE over the 17-year period from 1995-2011 using a TGARCH model taking account of time-varying volatility. The study reported little statistical evidence of a monthly anomaly in mean returns, however their study documented evidence of monthly patterns in the volatility of returns in the KSE.

Thus, a review of the literature revealed that all studies employed quantitative analysis to examine the presence of Islamic calendar anomalies; no previous research in this area had sought the views of the stock market participants when investigating the presence of Islamic calendar anomalies. This lack of a qualitative research on Islamic calendar anomaly remains noticeable in the literature. Despite the contradictory nature of the findings in the prior studies, it is surprising that no attempt has been made to discuss Islamic calendar anomalies with those involved in the running of the market; therefore, the insights of market participants about this topic should be canvassed. Furthermore, an interview-based investigation will help explore whether the Islamic calendar effect found in literature is actually exploited by the participants of the Pakistani stock market.

The current study adds a qualitative perspective to this topic. This study makes an important contribution to literature by conducting interviews with practitioners to ascertain views about the role of investor sentiment in the Pakistani stock market and whether returns vary from one Islamic month to another where the different months from the Islamic calendar are associated with various sentiments. This is the first detailed study to gain the perception of market participants in Pakistan with regards to calendar anomalies and whether investor sentiment has a role to play in explaining any anomalous behaviour. 


\section{Methodology and sample selection for the interviews}

19 face-to-face interviews conducted with brokers, regulators and individual investors in the city of Karachi. The semi-structured interview questions involved a mixture of open-ended and close-ended questions in order to gather knowledge about practitioners' thoughts on the operations of the KSE as well as to obtain the views of the people involved in the trading of shares on daily basis. Table 1 summarises the background information about each of the 19 interviewees. Each interviewee was assigned a code in order to maintain their anonymity and protect the confidentiality of the respondents. As Table 1 indicates, the interviewees included 14 brokers[4], 3 regulators at the KSE, and 2 individual investors - one of these was a high net worth investor with an average monthly investment of 1 billion rupees. Thus, the interviewees had an in-depth knowledge of the topics being discussed, were articulate with their comments and capable of offering insights into the issues covered within the semistructured interviews. The questions asked in each interview were related to the background of each interviewee; for example, all brokers and regulators were queried on their perceptions about Pakistani investors as a whole, whereas individual investors were asked about their own personal views on their own behaviour[5].

Each interview questionnaire comprised 30 semi-structured questions, 7 of which related to background information about the interviewees while the remaining 23 questions dealt with their views regarding the monthly calendar anomalies in the Pakistani stock market and whether investor sentiment has a role to play in explaining any anomalous behaviour in the market. With the exception of two[6] of the interviews, all discussions were digitally recorded with the consent of the interviewees[7]. These recordings were later analysed to arrive at the results. In addition to the recordings, the 
researcher took notes during each interview about the main points that the interviewee raised. Following each interview the tape-recording was played and the manuscript notes taken at each meeting were analysed; important points made were then noted. Once all the interviews were complete, an Excel sheet was used to summarise the essential replies identified in each interview in order to highlight core findings. This also facilitated the identification of prominent views as well as patterns in the interview data and assisted the research process by identifying apparent contradictions among the main views expressed. The main observations that emerged form the basis of the findings are reported and discussed in the next section.

\section{Results and discussions}

This study analyses the views of Pakistani participants about share price behaviour around the Islamic calendar. In particular, this section reports the views of brokers, regulators and individual investors who are involved in share trading on a daily basis. In addition, the study attempts to investigate whether investor sentiment amongst market participants has a role to play in explaining any anomalous behaviour in market prices with regards to Islamic calendar months.

\subsection{Islamic calendar and investment practice in Pakistan}

Interview respondents believed that Islamic principles underpinned the security analysis and equity decision making of investors in Pakistan. Four of the 12 Islamic calendar months were mentioned by the interviewees as periods when patterns were present in security returns (Ramadan, Muharram, Safar and Zil Hajj). For example, Interviewee BR12 noted that:

"Trading varies mostly in the month of Ramadan. There has been a trend [in security performance] in this month for the past 5 to 10 
years. Since people believe it's a blessed month according to Islamic teachings, there is this hope that the market will show a positive trend and therefore people take additional risk based on that hope. This leads to increased trading volume and therefore trends can be seen [since demand for equities exceeds supply]. It could be that the market goes down one or two days but the overall trend is upwards during Ramadan.”

This finding ties in with the prior literature that argued that religious beliefs can have an impact on investment practices (Weber, 1930; Al Ississ, 2010; Bialkowski et al., 2012). This interviewee also mentioned that patterns were present in other months of the Islamic calendar. For example he argued that:

"The month of Safar [the second month of the Islamic calendar] also shows trends. It is believed that this is a difficult month as a lot of difficulties came to Muslims in this month at the time of Prophet Muhammad and therefore people stop their investments and avoid investing in this month. If you look at the last 10 year trend for the month of Safar you'll see that either the market is going down or something's wrong with the market; people just generally avoid investing at this time of the year".

He also added that "in the month of Muharram, the Shia community freeze their investments as they are generally busy in mourning the very tragic incident that took place many years ago [i.e. the Battle of Karbala] . In Zil Hajj, the last month of Islamic calendar, it was suggested that the volumes also decline due to the fact that many Muslim investors go to Mecca for the Haj (pilgrimage). So trends and patterns could be found if you take all this into account.” Thus, suggesting that the Islamic calendar often drives investment practice in Pakistan.

These views were different from the findings of Mustafa (2008) where the author documented no Ramadan effect in Pakistani security returns over the period March 1998 September 2004. They are also inconsistent with the results of Husain (1998) and Halari et al. (2015) where the authors discovered that there was a significant decline in the volatility of share returns in the month of Ramadan; far from increasing 
risk as BR12 suggested, prior research suggested that risk fell during Ramadan. Interviewee BR12 also highlighted that share returns might be predictable during the months of Ramadan and Safar. He also suggested that "in Ramadan there is normally an upward trend in share prices". Once he spotted this trend, he then "checked for a reverse pattern in the month of Safar". He suggested that "in Safar, the market underperformed [on the basis of very little activity]"; he attributed this underperformance in the month of Safar to "a generally negative mind-set” among the population. Again, linking to the behavioural finance theory presented by previous literature.

Speaking of the month of Muharram, the respondents associated the Muharram effect with the law and order situation in the country and with the mourning observed by the Shia Muslims in this particular month of the Islamic calendar. Shia Muslims mourn the martyrdom of Hussein ibn Ali, the grandson of the Prophet Mohammad at the Battle of Karbala on Ashura during Muharram (Al-Assis, 2010). In the same context, the response of IND1 was typical when he mentioned that:

"Muharram is the month when Shia-Muslims are busy mourning for the martyrdom of Imam Hussain and Imam Hassan. Thus, they pay less attention to the market during this period. Also, because the law and order situation is tense in this month because more often than not there is some sort of clash or riot [between Sunni and Shia Muslims who adopt different approaches to this month]. Especially on the $9^{\text {th }}$ and $10^{\text {th }}$ of Muharram.”

When asked "why security trading might vary with Islamic religious events", the most common reply was that investors focused more on religion at the time of these events and attendance at the market was down. In addition, the shortening of trading hours during these events further reduced volumes as well as liquidity suggesting that market regulation also has an impact on the investment practices. 
An individual investor, interviewee IND2, pointed out that the KSE also attracts a growing amount of "foreign investment as well so sometimes if there is Christmas, New Year or a Chinese holiday”, there is "a slowdown in the [inflow of] foreign funds and that results in a decline in the overall volume as people tend to follow [the lead of] foreign investors". He stated that "if the activity of foreign investors declines, local investors also stay away from the market.” Implying that volatility is also low during non-Islamic holidays.

Again, it is quite clear from the interviewees that the Islamic religion has an influence on security trading and stock market performance in Pakistan and market participants were aware of the anomalies highlighted in literature. Most interviewees suggested that trading patterns could be identified in different Islamic months which could be predicted and exploited to generate abnormal returns. For example, Interviewee BR2 stated that his brokerage firm had "a technical research team that was specifically looking for these patterns" in order to advise their clients about when to invest. BR11 disagreed slightly with this view. He argued that over the longer term, new information was eventually incorporated into the share prices and that these prices fully reflected all of information contained in past prices, such that investors could not outperform the market. However, BR11 admitted that profits might still be made by exploiting patterns in the short term. For example, he noted that "when everybody tries to [exploit a regularity in returns] those patterns fade". However, he suggested that "for certain periods ... following the identification of those patterns, an investor can earn good money.” His response indicated that information was not impounded into the share price in a rapid fashion and there were times when investors could beat the market. These findings are consistent with a majority of the studies of the Pakistani stock market 
which document that the Pakistani stock market is not weak-form efficient (Kamal and Nasir, 2005; Shaheen, 2006 and Ali and Akbar, 2009).

\subsection{The month of Ramadan}

Although some interviewees mentioned that returns in other Islamic months could be predictable, the most common pattern highlighted related to the month of Ramadan. Some 18 of the 19 interviewees mentioned that the period of Ramadan had an effect on the stock market in Pakistan[8]. By contrast, for the next most mentioned month, the month of Muharram, only 6 of the 19 interviewees highlighted that share performances was predictable as well.

In support of Al-Ississ's (2010) findings, most of the interviewees suggested that market returns were positive in the month of Ramadan. For instance, interviewee BR2 mentioned that:

"Trading volumes and market performance picks up before Ramadan... Some of the investors become more religious and they don't opt for leverage products in the month of Ramadan because it's not allowed in Islam. Volumes are generally low [during the month] as well because the trading hours are shortened in Ramadan[9]. For the past ten years, since I have been in this market, Ramadan coincides with a bullish period in the market. Usually technical analysis shows us that the typical Bull run starts from September/October and lasts until March/April. If you study the calendar for last 10 years, you will see that Ramadan has fallen during August to February."

Interviewee BR2 suggested that the link between Ramadan and a bull market was a mere coincidence. However, other respondents associated this effect with the shortening of the trading times and the increased devotion among investors to prayers. For example, interviewee RE3 stated that: 
"During Ramadan we have shorter trading times. Normally the timings are 9:30 - 15:30 but in the month of Ramadan the trading time is 9:00 - 14:00. The volume and average trading per day therefore comes down because of the shortening of the time [for trading]. A lot of investors are not interested in investing during the month of Ramadan because their thoughts are diverted to preaching, fasting and 'Taraweeh'[10] so they don't work. A lot of people also travel to the Umrah[11] [and so are not around to trade].”

This comment was in line with the findings from Husain (1998) and Halari et al. (2015) where the authors discovered that equity price volatility was lower in the month of Ramadan. Six of the respondents claimed that this effect was not present during the whole period of Ramadan but was concentrated in the final weeks of the holy festival; they suggested that volumes were quite thin in the last 10 days of Ramadan[12]. They attributed this thin trading to the fact that a lot of investors are out of the country for religious reasons towards the end of this month. In this context, respondent RE1 mentioned that the "attendance at the stock market is low especially in the last 10 days of Ramadan when people go to Saudi Arabia for Umrah and prayers”. As a result, he noted that "there were fewer shares changing hands and fewer settlements [in this period]”.

\subsection{The Memon community}

Indeed what was really interesting, and one of the key findings of this study was that interviewees mentioned the prominence of the "Memon" community in the Pakistani stock market. The interviewees suggested that individuals from this community essentially had an influence on the level of trading around Muslim festivities; this community were religious and concentrated on Islamic practices more in Ramadan rather than their equity investments. For example interviewee BR11 stated 
that during the "last ten days [of Ramadan], because the brokerage industry is dominated by the business community called Memons, [trading declines] because they focus more on religion and forget about business.” Interviewee BR8 concurred with this observation; he commented that "most of the participants in the market belong to a particular community called the Memons and this community, especially in Ramadan, practices Islam very strictly and enthusiastically.” Thus, based on the comments made by interviewees, it can be said that Islamic principles are more important than material influences when undertaking stock market investing for the Memon community in the month of Ramadan.

The Memon community are well-known to be entrepreneurial, business minded and religious. Interviewees in the current study and prior research confirm that Memons are the most active community in the Pakistani stock market (Muhammad and Dana, 2015) and highlight the influence of this community on share trading the Pakistani stock market. This is an interesting insight which was missing in the prior research. Following the behaviour of this community may help investors make informed decisions about timing their investments.

\subsection{Investor sentiment and the Islamic calendar}

The researcher then sought respondents' opinions on the importance of investor sentiments associated with investment in Pakistan as the literature indicates that investor sentiment may have a role to play in explaining investor behaviour. The questions focussed on asking whether the interviewees believed that investor sentiment had any role to play in explaining any anomalous behaviour of the stock market. For example, the interviewees were asked about whether "emotions and sentiments have 
any effect on decision making, risk assessment, equity valuation and investment practices”.

The Chief Executive Officer of a brokerage firm, BR11, gave an example of how a cricket match could change the investor sentiments and in turn influence the stock market. For instance, he stated that:

"If there is a cricket match [with Pakistan winning] people are happy so they want to buy more shares; they don't want the market to fall. They may be busy watching the cricket but they still don't want the market index to decline”.

He suggested that at times investment was “all about emotions.” Interviewee, RE3, one of the directors of the KSE agreed with this point of view when he noted that:

"When the people are happy they are even interested in buying at higher prices like when there is a big joyous occasion for the nation there is [a wave of] emotional buying as well. For example, when Pakistan won the [cricket] world cup everybody was so happy that the next day the market went up by more than 100 points."

Individual investor, Interviewee IND1, gave a more recent example of the same phenomenon. He noted that if he was "in a positive mood" he might be "willing to take on more risk than he would normally do”. He suggested that the same approach “applied for the whole nation as well; for example, if the whole nation is in a positive (negative) mood then market will experience a positive (downward) trend”. For instance, he pointed out that when President Benazir Bhutto was assassinated "the market remained shut for a few days and after it re-opened people were very reluctant to put their money in equities". In fact he suggested that "investors were scared because of the political situation and some pulled their capital out of the market; as a result the Index started decreasing drastically”. So he argued that:

"Emotions and mood have a big impact on the market especially when a majority of the population is going through similar emotions 
and experiences. Ideally this should not be happening as investors don't think rationally but unfortunately it does happen, especially when they are assessing the risk of the securities. Emotions are generally short term and affect shares on an individual basis. However mood is long term and things like the state of the economy and the law and order situation affect mood of more than just individuals."

There was less disagreement amongst the respondents about whether various religious events affected investor sentiments differently. Apart from the brokers BR4 and BR14 and investor IND2 all agreed that they did. Broker BR2 was typical in his response when he noted that:

"Yes, Muharram does have an effect on investor mood. Usually people that belong to the Shia sector don't trade in the month of Muharram and there is a fair share of those people in the market; they postpone their investment in that month. Also in the month of Ramadan, Muslims are fasting, their energy level is low and that affects the mood as well."

Individual investor, IND1, agreed with this general view noting that:

"The months of Muharram and Safar generally have a negative impact on my mood because of the events that took place involving Muslims many years ago; it is not just my mood but the mood of the whole country that is affected. However in Ramadan there is a positive feeling of goodwill throughout the nation because people are generally happy; they are out shopping for their families for Eid and socialise more."

Some investors associated mood at the time of religious events with trends in security prices and risk. For example, BR13 mentioned that "in the month of Muharram investor mood is generally very negative. There are a lot of security issues in this month as well and so the market is normally slow in this month. This is especially true on the $9^{\text {th }}$ and the $10^{\text {th }}$ day of Muharram because of the security fears”. BR3 noted that "Ramadan had a positive impact on the mood. If you look at the history, the market has 
always been positive in Ramadan and the public follows these previous trends and a greater amount of speculation occurs.”

In a group interview with four brokers (BR6, BR7, BR8 and BR9), broker BR6 implied that the mood was generally positive in the month of Ramadan, consistent as indicated by prior research (Al-Ississ, 2010; Bialkowski et al., 2012; and Al-Khazali, 2014) and that there was a slowdown in the market especially in the last 10 days of Ramadan. Another broker, BR8 argued that:

"In Ramadan activity is slack for another reason which is extremely logical and simple to understand: namely the trading hours are shorter. So you have less time to think [about equities] and make your investment decisions and this has an effect on the overall performance of market as well."

Broker BR6 disagreed with his view, however, noting that "in the days when the market used to always close at 1:00PM there was no difference in the timings of trading in Ramadan [and non-Ramadan months]; but still the volumes were low in Ramadan.”

From these responses it would appear that investor sentiment has an impact on the stock market and religious events impact on sentiments differently; these impacts are transmitted to the stock market; hence, a number of respondents suggested that investor sentiment could explain patterns in terms of trading behaviour for certain months of the Islamic calendar. Thus, it could be concluded that emotional biasness and the use of the Islamic calendar influences investment practice in Pakistan.

\section{Conclusion}

We conducted a qualitative investigation of Islamic calendar anomalies in the Pakistani stock market. This study provides detailed evidence about the views of 
influential participants (investors, brokers and regulators) who are involved in the running of the Pakistani stock market.

A number of findings have emerged from this interview-based investigation; the results of the interviews suggest that most respondents were aware of anomalies present in the market and believed that share prices exhibit patterns in certain months of the Islamic calendar which they were actively attempting to exploit for abnormal gains. The most common pattern highlighted by the interviewees related to the month of Ramadan. Interviewees also argued that volatility declined during the religious month of Ramadan; they attributed these changes to investor sentiment and religious duties. Interviewees mentioned three other months when they believed that share prices could be predicted; these months were Muharram (the cultural and religious split between Shia and Sunni Muslims and the riots and security issues during Muharram impacts on investment practice), Safar (which Muslims believe is a difficult month as a lot of difficulties were experienced by Muslims in this month at the time of Prophet Muhammad) and Zil-Hajj (when Muslim investors go to Mecca, Saudi Arabia for the annual pilgrimage). Nevertheless, although some interviewees mentioned that returns in other Islamic months could be predictable, the most common pattern highlighted related to the month of Ramadan.

Several interviewees highlighted the influence of "Memon" community on share trading in the KSE; they suggested that individuals from this community essentially influenced the level of trading around Muslim festivities, especially during the month of Ramadan. According to the interviewees, this community were deeply religious and concentrated more on Islamic practices rather than their equity investments in Ramadan. As a result, the volume of share trading declined during certain Islamic months and equity returns became less volatile as a result. Further, the 
reduced share trading hours during Ramadan combined with the fasting requirements as well as other religious observances were all thought to draw investor attention away from security transactions. Overall, it can be said that as a symbolic carrier of the logic, the Islamic calendar drives material practice.

Interviews also suggested that investor sentiment played an important role in affecting the decision making, risk assessments and equity valuations of investors in Pakistan. The respondents believed that investor sentiment had an influence on stock market prices and the share trading of the investors. Therefore, the findings suggested that investor sentiment might explain any anomalous behaviour in the Pakistani stock markets around different Islamic months; this was particularly true for Ramadan, according to the interviewees, as they suggested that volatility declined in this religious month and attributed these changes to investor sentiment and religious duties - this area needs further investigation.

This study exhibits the importance of qualitative research approach particularly for the current investigation since all prior work on Islamic calendar anomalies adopted quantitative method using secondary data; indeed, the face-to-face research approach allows to fully explore the topic under investigation and allows to draw robust conclusions. The use of a qualitative method provided some interesting insights which were missing in the previous studies such as: possible explanations for anomalies; influence of a particular community in the stock market and; the role of investor sentiment in explaining any anomalous behaviour around different Islamic months. It is thus believed that the study makes an important contribution to the existing knowledge regarding Islamic calendar anomalies in the Pakistani stock market. Findings from this study suggest the importance of Islamic belief in investment practice. These findings may aid the regulators in better understanding the behaviour 
of stock market participants based on the Islamic calendar to improve its efficiency.

Testing whether these results are exclusive to Pakistani stock market or common across majority Muslims markets as a whole would be an interesting avenue for future research.

Notes

1. The day of Ashura falls in the month of Muharram. The day of Ashura is seen by Muslims as a day of mourning for the martyrdom of Hussain ibn Ali, the grandson of the Islamic Prophet Muhammad, at the Battle of Karbala on 10 Muharram.

2. The interviews focussed on people who are involved in daily share-trading within the stock market since these should be the most knowledgeable about the research questions being asked.

3. Ashoura is the 10th day of the month of Muharram in the Islamic calendar. It marks the climax of the remembrance of the battle of Karbala.

4. 2 of these were the CEO's of their brokerage houses, 2 were Chief Executives and 2 were Directors of their brokerage firms. Of the remaining 8 brokers, 3 had the title "Head of Equity Sales", 2 were Vice Presidents of Equity Sales, BR1 was a Senior Manager while BR5 was a KATs Operator and BR8 was an Equity Trader.

5. Two types of semi-structured questionnaire were used; one questionnaire for brokers and regulators whilst the other was designed for individual investors. Copies of the questionnaires used in the interviews can be provided upon request.

6. Interviewee RE1 is a regulator within the KSE and therefore it was not possible for the interview to be recorded whereas IND1 did not allow the conversation to be recorded.

7. All interviews were in English and were transcribed word-for-word. However, where interviews contained Urdu, or a mixture of English and Urdu, they were translated and important quotations were noted.

8. Two of the 18 interviewee's mentioned Ramadan effect but said that there is no longer any Ramadan effect in the market. Whereas IND2, said that his trading did not vary with the Islamic calendar however the general volumes in Ramadan goes down. Interviewee BR14, did not answer the question.

9. $\quad$ This was mentioned in the study by Husain (1998).

10. Extra congregational prayers performed by Muslims at night in the month of Ramadan.

11. Pilgrimage performed by Muslims in Saudi Arabia.

12. A study by Al-Assiss (2010) found that the last 10 days of Ramadan have a higher return than the first ten days ( 0.18 percent vs. 0.07 percent). The author associated this with positive investor sentiment. 


\section{References}

Al-Hajieh, H., Redhead, K., and Rodgers, T. (2011), "Investor sentiment and calendar anomaly effects: A case study of the impact of Ramadan on Islamic Middle Eastern markets”, Research in International Business and Finance, Vol. 25 No. 3, 345-356.

Ali, S. and Akbar, M. (2009), "Calendar Effects in Pakistani Stock Market", International Review of Business Research Papers, Vol. 5, pp. 389-404

Al-Ississ, M. (2010), “The impact of religious experience on financial markets", Working paper. Harvard Kennedy School of Government.

Al-Khazali, O. (2014), "Revisiting fast profit investor sentiment and stock returns during Ramadan”, International Review of Financial Analysis, 33, 158-170.

Almudhaf, F. (2012), “The Islamic calendar effects: Evidence from twelve stock markets”, International Research Journal of Finance and Economics, Vol. 87, 185-191.

Bialkowski, J., Etebari, A., and Wisniewski, T. (2012), "Fast profits: Investor sentiment and stock returns during Ramadan”, Journal of Banking and Finance, Vol. 36 No. 3, 835-845.

Clark, M.S. and Isen, A.M. (1982), “Toward understanding the relationship between feeling states and social behavior." In A. Hastorf and A. M. Isen (Ed.), Cognitive Social Psychology, New York: Elsevier North-Holland, pp. 73-108.

Edmans, A., Garcia, D. and Norli, Ø., (2007), "Sports sentiment and stock returns”, The Journal of Finance, Vol. 62 No. 4, pp.1967-1998.

Gardner, M.P. and Vandersteel, M. (1984), “The Consumer's Mood: an Important Situational Variable", in Advances in Consumer Research, eds. Thomas C. Kinnear: Association for Consumer Research, Vol. 11, pp. 525-529.

Halari, A., Tantisantiwong, N., Power, D.M., and Helliar, C. (2015), "Islamic calendar anomalies: evidence from Pakistani firm-level data”, The Quarterly Review of Economics and Finance, Vol. 58, 64-73.

Hirshleifer, D. and Shumway, T. (2003), "Good day sunshine: stock returns and the weather”, Journal of Finance, Vol. 58 No. 3, 1009-1032.

Husain, F. (1998), "A seasonality in the Pakistani equity market: The Ramadhan effect”, The Pakistan Development Review, Vol. 37 No. 1, 77-81.

Kamal, Y. and Nasir, Z. M. (2005), "Day of the Week Effect in Stock Return Evidence from Karachi Stock Market”, Unpublished Working Paper, Available at SSRN: http://ssrn.com/abstract $=829524$ 
Keef, S.P. and Khaled, M.S. (2011), “Are investors moonstruck? Further international evidence on lunar phases and stock returns”, Journal of Empirical Finance, Vol. 18 No. 1, pp.56-63.

Muhammad, N. and Dana, L.P., 2015. Collective Efficacy of a Regional Network: Extending the Social Embeddedness Perspective of Entrepreneurship. Unpublished Working Paper, Available at SSRN: https://papers.ssrn.com/sol3/papers.cfm?abstract_id=2749376

Mustafa, K. (2008), “The Islamic calendar effect in Karachi stock market”, Proceedings of the 8th International Business Research Conference, Dubai, UAE. Available at: http://www.wbiconpro.com/313A---Mustafa,K.pdf (accessed 15 January 2016)

Rehman, A.A. and Masood, O. (2012), "Why do customers patronize Islamic banks? A case study of Pakistan”, Qualitative Research in Financial Markets, Vol. 4 No. (2/3), pp.130-141.

Saunders, E. M. J. (1993), "Stock prices and wall street weather", American Economic Review, Vol 83 No. 5, 1337-1345.

Seyyed, F., Abraham, A., and Al-Hajji, M. (2005), "Seasonality in stock returns and volatility: The Ramadan effect", Research in International Business and Finance, Vol. 19 No. 3, 374-383.

Shaheen, R. (2006), "Stock Returns and the Day of the Week Effect: Karachi Stock Exchange", Presented at The All China Economics (ACE) International Conference, December 18-20, 2006.

Weber, M. (1930). The Protestant Ethic and the Spirit of Capitalism. New York: Scribner's. 
Table 1 Interviewee Details

\begin{tabular}{llllr}
\hline Code & Age & Job title & Brokerage house/Firm & Experience \\
\hline BR1 & $31-40$ & Senior Manager - Equities & Foundation Securities & 7 \\
BR2 & $31-40$ & Head - Equity Sales & Foundation Securities & 9 \\
BR3 & $31-40$ & Chief Operating Officer & Multiline Securities & 10 \\
BR4 & $31-40$ & Chief Operating Officer & FDM Securities & 19 \\
BR5 & $21-30$ & KATs Operator & FDM Securities & 5 \\
BR6 & $21-30$ & Assistant Vice President International Equity Sales & BMA Capital Management & 6 \\
BR7 & $21-30$ & Vice President - Equity Sales & BMA Capital Management & 11 \\
BR8 & $31-40$ & Equity Trader & BMA Capital Management & 7 \\
BR9 & $21-30$ & Head - International Equity Sales & BMA Capital Management & 6 \\
BR10 & $31-40$ & Director & Arif Habib Management Ltd & 9 \\
BR11 & $41-50$ & Chief Executive & Alfalah Securities & 19 \\
BR12 & $41-50$ & Head of Sales & ZHV Securities & 8 \\
BR13 & $21-30$ & Director & ZHV Securities & 10 \\
BR14 & $41-50$ & Chief Executive & Intermarkert Securities & 20 \\
RE1 & $41-50$ & Manager Research & The Karachi Stock Exchange & 17 \\
RE2 & $41-50$ & Director & The Karachi Stock Exchange & 25 \\
RE3 & $41-50$ & Director & The Karachi Stock Exchange & 23 \\
IND1 & $41-50$ & Manager & Al-Munaf Coeporation & 18 \\
IND2 & $31-40$ & Vice President - International Sales & Arif Habib Management Ltd & 4 \\
\hline
\end{tabular}

Note: This table presents the summary details of the interviewees. In particular, the table shows the age group, job title, brokerage house/firm and number of years of experience in the market. All interviews were conducted in the city of Karachi. Each interview was assigned a code. BR refers to Broker, RE refers to Regulator and IND refers to individual investors. 